\title{
UKRAIŃSKA LOKALIZACJA OPROGRAMOWANIA KOMPUTEROWEGO: ZARYS PROBLEMU
}

\author{
PRZEMYSŁAW JÓŹWIKIEWICZ \\ Uniwersytet Wrocławski, Wrocław — Polska \\ УКРАЇНСЬКА ЛОКАЛІЗАЦІЯ ПРОГРАМНОГО ЗАБЕЗПЕЧЕННЯ: \\ ПОСТАНОВКА ПРОБЛЕМИ \\ ПШЕМИСЛАВ ЮЗВІКЕВИЧ \\ Вроцлавський університет, Вроцлав - Польща
}

АНОТАЦІЯ. У статті обговорено проблеми, пов'язані з перекладом програмного забезпечення, здійсненого українською мовою. Особливу увагу приділено законам, що впливають на стан IT-ринку України та роботу українських перекладачівкомп’ютерників щодо налагодження ПЗ для україномовних користувачів.

\section{UKRAINIAN LOCALIZATION OF THE SOFTWARE: OUTLINE OF THE PROBLEM}

\author{
PRZEMYSŁAW JÓŹWIKIEWICZ \\ University of Wroclaw, Wroclaw — Poland
}

ABSTRACT. The article surveys the problems concerned with the translation of IT products into Ukrainian. Special attention was devoted to the regulations that affect the state of the Ukrainian IT market and the work of Ukrainian IT translators in terms of customization of software for the Ukrainian recipient.

U kraińskojęzyczne oprogramowanie komputerowe, podobnie jak i literatura informatyczna w języku ukraińskim stanowi w zasadzie produkt niszowy, bowiem sytuacja na ukraińskim rynku technologii informacyjnych, a mam tu na uwadze zarówno oprogramowanie komputerowe, zasoby sieciowe, jak i ofertę wydawnicza, jest w wysokim stopniu zdominowana przez produkty rosyjskojęzyczne. Stan ten utrzymuje się od wielu już lat i niewiele wskazuje na to, by miała w tej kwestii nastąpić jakaś znacząca zmiana.

Genezy takiej, a nie innej kondycji szeroko pojętej ukraińskojęzycznej produkcji w dziedzinie IT należy doszukiwać się już w latach 60.-70. minionego stulecia. Wprawdzie podjęto wówczas pierwsze próby stworzenia ukraińskich zasobów terminologicznych opisujących techniki obliczeniowe, jednak fakt ten należy rozpatrywać jedynie w kategoriach wyjątku, ponieważ językiem naukowców pracujących w ukraińskich zespołach badawczych był przede wszystkim język rosyjski. Wysiłek nad stworzeniem podstaw ukraińskiej terminologii komputerowej bezpośrednio związany był z pracami nad Encyklopedia cybernetyki — dzieła, które ostatecznie ukazało się w dwóch wariantach: ukraińskim ${ }^{1}$, w roku 1973 oraz rosyjskim, w rok później. Wśród autorów poszczególnych haseł znaleźli się uczeni z obszaru całego ZSRR. Jak nietrudno się domyślić, hasła nadsyłane do redakcji

${ }^{1}$ Енциклопедія кібернетики в 2 m., за ред. В. М. Глушкова, Київ 1973. 
były opracowane $\mathrm{w}$ języku rosyjskim. Z racji przyjętych założeń redakcyjnych, musiały być one tłumaczone na język ukraiński. Proces ten, niezwykle trudny i żmudny, utrudniał fakt, iż przekład nie ograniczał się do zwyczajowych działań translatorskich - należało bowiem stworzyćc ${ }^{2}$ od podstaw większość terminów, gdyż po prostu nie istniały one w języku ukraińskim. Były to zatem pierwsze zabiegi tłumaczeniowe w obrębie ukraińskiej leksyki informatycznej.

Jak jednak wspomniałem, próbę tę należy uznać za udaną jedynie połowicznie, ponieważ ukute wówczas terminy $\mathrm{w}$ praktyce nie funkcjonowały w ukraińskim środowisku informatycznym, dla którego platformą komunikacji w znakomitej większości pozostawał język rosyjski.

Sytuacja nie ulegała w zasadzie zmianie przez kolejne dwie dekady. Wprawdzie ukazała się w tym czasie pewna ilość publikacji z zakresu informatyki w języku ukraińskim, lecz można śmiało stwierdzić, że były to jedynie odstępstwa potwierdzające regułę.

Za obecną $\mathrm{w}$ literaturze przedmiotu tezą o dwuetapowości powstawania i rozwoju ukraińskiej terminologii informatycznej optuje m.in. Lilija Filuk ${ }^{3}$, która pierwszy etap umiejscawia w epoce komunistycznej, gdy, jak stwierdza uczona, „[...] будь-яка термінологія, механічно копіювалася з російської”. Sytuacja ta, pisze badaczka, była rezultatem zakazu z lat 30. dotyczącego tworzenia oryginalnej terminologii ukraińskiej oraz faktu, iż środowisko, w którym rodziła i rozwijała się myśl informatyczna, było niemalże w całości rosyjskojęzyczne. Etap ten, kontynuuje autorka, charakteryzował się zupełną wtórnością, a na język ukraiński tłumaczono teksty rosyjskie, orientując się przy tym na rosyjski system terminologiczny.

Druga faza rozwojowa wiąże się nierozerwalnie z uzyskaniem przez Ukrainę niezależności państwowej, otwarciem na Zachód, tworzeniem słowników terminologii informatycznej, wprowadzaniem głównie amerykańskich technologii informatycznych, czemu towarzyszyło ukierunkowanie w tej dziedzinie nauki na terminologię anglojęzyczną. L. Filuk ${ }^{4}$ zauważa, że dochodziło przy tym niejednokrotnie do tworzenia niepotrzebnej synonimii, np. електронно-обчислювальна машина (EOM) комп'ютер, алфавітно-цифровий друкувальний пристрій - принтер, графопобудовник - плоттер, розв'язуючий пристрій-процесор і in.

Dziś, i tu znów wypada zgodzić się z autorką artykułu, gdy podwaliny ukraińskiej terminologii informatycznej są już położone, powinien rozpocząć się trzeci etap unifikacja i dalsza standaryzacja terminologii, w której decydującą rolę odgrywać będą specjaliści z zakresu leksykografii, terminoznawstwa i informatyki. Jest to niezmiernie ważne, bo, jak podkreśla Ałła Lipinśka ${ }^{5}$, dzięki temu wyraźnej poprawie ulegnie jakość przekładów literatury informatycznej na język ukraiński, a co za tym idzie zwiększy się ilość publikacji z dziedziny IT w języku ukraińskim.

Istnienie słownictwa informatycznego jako integralnej składowej języka ukraińskiego od strony prawnej reguluje kilka aktów prawnych. Najważniejszym

${ }^{2}$ Myrosław Kratko, jeden ze współtwórców dzieła pisał tak: „Важку роботу перевести все на українську мову взяла на себе редакція літературного контролю УРЕ. Пишу "перевести”, а не "перекласти", бо це справді була робота не тільки перекладацька, а й термінологічна, адже українських кібернетичних термінів ще не було". Електронний ресурс: http://www.istpravda.com. ua/digest/4d4fb3c09e453/ (12.10.2011)

3 Л. М. Філюк, Основні етапи формування украӥнської терміносистеми інформатики, [в:] „Культура народов Причерноморья” Симферополь 2006, № 82, т. 2, с. 202-204.

${ }_{4}^{4}$ Л. М. Ф іл ю к, Шляхи подолання варіантності в українській терміносистемі інформатики, [в:] „Записки з українського мовознавства” Одеса 2009, вип. 18, с. 238-249.

${ }_{5}^{5}$ А. Л і п і н с ь ка, Проблеми комп'ютерної термінології української мови, [в:] Газета „Університет «Україна»" 2003, № 4-5. 
z nich jest rzecz jasna Konstytucja Ukrainy i podstawowe stwierdzenie, iż „Державною мовою в Україні є українська мова"6. Kolejne zapisy, m.in. postanowienie ${ }^{7}$ ukraińskiego Trybunału Konstytucyjnego z dnia 14 grudnia 1999 r., a zwłaszcza mający jeszcze do niedawna ${ }^{8}$ zastosowanie fragment Ustawy o językach $w$ Ukraińskiej SRR dotyczący języka w sferze informatyki ${ }^{9}$ wskazują na wiodącą rolę języka ukraińskiego na Ukrainie, jednakże w kwestii języka wykorzystywanego w dziedzinie IT de facto zrównują status języka ukraińskiego i rosyjskiego.

Wydaje się, że to m.in. ten akt prawny, chociaż przyjęty prawie ćwierćwiecze temu, wydatnie rzutował na rozwój ukraińskiego języka IT w warunkach niezależnego państwa ukraińskiego. Dziś widać, iż faktyczne ustawowe zrównanie obu języków w tej dziedzinie miało bardzo duży wpływ na funkcjonowanie języka rosyjskiego w ukraińskiej sferze technologii informacyjnych.

Kolejne rozwiązania legislacyjne, jak np. w Ustawa o narodowym programie informatyzacji ${ }^{10} \mathrm{z}$ lutego $1998 \mathrm{r}$. czy dokumenty późniejsze, zasadniczo niczego w tej kwestii nie zmieniły. Efektem takiej polityki, są dziś wyraźne trudności ukraińskojęzycznych użytkowników komputerów. Ograniczony jest dostęp do legalnego oprogramowania w języku ukraińskim, publikacji, zauważalne są również problemy w zakresie rozwoju ukraińskiej terminologii informatycznej, co tłumaczyć można m. in. spuścizną po języku rosyjskim, ale i postępującym wpływem języka angielskiego.

To właśnie z racji tych oddziaływań, a w okresie ostatniej dekady znacznych wpływów angielskich, bardzo ważną kwestią pozostaje problem przekładu na język ukraiński słownictwa wykorzystywanego w sferze IT.

Niezmiernie istotne jest tu korzystanie z systemów operacyjnych w języku narodowym. Najczęściej stosowane systemy operacyjne na świecie, a więc seria Microsoft Windows, funkcjonują w komputerach osobistych już od połowy lat osiemdziesiątych, jednak ich prawdziwa popularność zaczęła się na początku lat 90., z chwilą pojawienia się na rynku systemu Windows 3.11, a później Windows 95. Za rynkowym sukcesem tych produktów przemawiały nie tylko rewolucyjne rozwiązania, ale także fakt, iż były to już systemy dostępne w wielu wersjach językowych. Zabrakło wśród nich języka ukraińskiego.

Sytuacja poprawiła się nieco w 2002 r., kiedy to pojawiły się oficjalne ukraińskie nakładki językowe dla programów MS Word 2002 i MS Outlook 2002 dostępne w pakietach MS Office XP Professional i MS Office XP Small Business. Z różnych

${ }^{6}$ Конституція Украӥни, Київ 1997.

${ }^{7}$ Рішення Конституційного Суду України, [в:] Електронний ресурс: http://zakon3.rada.gov. ua/laws/show/v010p710-99/ed20120412/paran54\#n54 (12.05.2012). Zob. m.in. zapis: „,_..> українська мова як державна є обов'язковим засобом спілкування на всій території України при здійсненні повноважень органами державної влади та органами місцевого самоврядування (мова актів, роботи, діловодства, документації тощо), а також в інших публічних сферах суспільного життя, які визначаються законом (частина п'ята статті 10 Конституції України). Поряд з державною мовою при здійсненні повноважень місцевими органами виконавчої влади, органами Автономної Республіки Крим та органами місцевого самоврядування можуть використовувати російську та інші мови національних меншин у межах і порядку, що визначаються законами України".

${ }^{8}$ Ustawę o językach w Ukraińskiej SRR z 1989 r. zastąpiła ustawa № 5029-VI (rozdz. X, ust. 2).

${ }^{9}$ We fragmencie tym czytamy, co następuje: „В Українській РСР інформатика здійснюється на основі української та російської мов. Комп’ютери, які використовуються в роботі державних, партійних, громадських органів, науково-дослідних, конструкторських установ, засобів зв'язку, у сфері торгівлі, обліку, постачання, в закладах освіти й культури, повинні забезпечувати можливість працювати з україномовними і російськомовними текстами".

10 Закон України Про національну програму інформатизації, [в:] Електронний ресурс: http://zakon2.rada.gov.ua/laws/show?nreg=74\%2F98\%E2\%F0\&find=1\&text=\%EC\%EE\%E2\%EE\%F $\mathrm{E} \& \mathrm{x}=5 \& \mathrm{y}=9(12.05 .2012)$. 
względów okazję do zapoznania się z tymi produktami miało niewielu ukraińskich użytkowników komputerów.

Rok później, w ramach odbywających się w Kijowie targów EnterEX, Microsoft zaprezentował ukraińską wersję systemu operacyjnego Windows XP Professional. Jednakże oferowany produkt ${ }^{11}$ nie był wersją stricte ukraińską, a jedynie nakładką instalowaną na rosyjskiej wersji językowej systemu. Nowsza wersja pakietu językowego, która pojawiła się 29 października 2003 roku, jak informowano: „3aбезпечує інтерфейс користувача мовою Ukrainian для більшості елементів інтерфейсу Windows XP..." Natomiast produktem językowo lepszym okazała się ukraińska wersja pakietu MS Office 2003 z 2004 roku.

Kolejny produkt Microsoftu, Windows Vista, miał swoją światową premierę w styczniu 2007 roku, zaś ukraiński wariant systemu operacyjnego pojawił się na ukraińskim rynku w maju tego roku. Istotnym novum było to, że warstwę językową systemu oparto, nie jak do tej pory na rosyjskiej, ale oryginalnej, amerykańskiej wersji. W jej tłumaczeniu na język ukraiński wykorzystano m.in. doświadczenia informatyków i językoznawców zdobyte w pracy nad projektem MS Community Glossary. Ukrainian Glossary.

Nowy system operacyjny rzecz jasna porównywano do poprzedniego, Windows $X P$, który w kwestii „ukrainizacji” okazał się produktem słabszym ${ }^{12}$. Wrażenia użytkowników ukraińskiej Visty zaczęły pojawiać się na forach poświęconych zagadnieniom komputeryzacji. Większość z nich dotyczyła problemów sprzętowych, jednakże były i takie, w których poruszano kwestie prawidłowości przekładu Visty na język ukraiński.

22 października 2009 roku rozpoczęto sprzedaż systemu operacyjnego Windows 7 , który swą ukraińską premierę miał 9 dni później wraz z ponad dwudziestoma innymi wersjami językowymi. Ukraińska wersja systemu operacyjnego początkowo dostępna była w wersji pudełkowej, preinstalowano ją również na 25 modelach komputerów stacjonarnych i laptopów. Jak stwierdził Dmytro Szymkiw, dyrektor generalny ukraińskiego oddziału Microsoft, Windows 7 był najbardziej oczekiwana wersją systemu operacyjnego w całej historii firmy. Wyraził on także zadowolenie, że i Ukraińcy będą mogli ocenić jego możliwości ${ }^{13}$. Sądząc po reakcjach ukraińskich użytkowników komputerów, z którymi można się zapoznać np. na forum portalu Домівка.Net, oczekiwali oni nie tylko na lepszą pod względem technicznym, ale również na wolną od błędów i w pełni zukrainizowaną wersję systemu operacyjnego.

Według danych na styczeń 2012 r. na świecie sprzedano ponad $500 \mathrm{mln}$ kopii systemu ${ }^{14}$, zaś sprzedaż Win7 na Ukrainie po roku obecności na rynku przewyższyła Windows Vista o 11\%. Świadczy to o dużej popularności systemu wśród ukraińskich użytkowników. Można przypuszczać, że wpływ na ten wynik mogła mieć nie tylko funkcjonalność systemu, ale i warstwa językowa produktu. Brak jednak oficjalnych i wiarygodnych danych dotyczących tego, która z wersji językowych, rosyjska czy ukraińska, jest przez użytkowników na Ukrainie kupowana częściej. Można pokusić się o przypuszczenie, że klienci zdecydowanie rzadziej wchodzą w posiadanie wersji oznaczanej symbolem UKR. Przyczyną takiego stanu rzeczy jest przede wszystkim

${ }^{11}$ Windows Ukrainian Interface Pack.

12 „Але у порівнянні з ХР прогрес все'дно значний! До того ж, працює 3 коробки, не треба було ставити щось, а потім пакет”, [в:] Електронний ресурс: http://forum.domivka.net/archive/ index.php/t-7315-p-5.html (30.11.2007).

13 Źródło elektroniczne: http://apitu.org.ua/node/1266 (04.06.2012).

${ }^{14}$ Electronic resource: http://www.microsoft.com/investor/EarningsAndFinancials/Earnings/Press ReleaseAndWebcast/FY12/Q2/default.aspx (04.06.2012). 
fakt, że ukraińscy dystrybutorzy oferują ${ }^{15}$ nabywcom głównie wersję rosyjską Win7.

Chęć (przynajmniej u części ukraińskiego społeczeństwa) do korzystania z ukraińskojęzycznego oprogramowania z pewnością istnieje. System operacyjny Windows 7, podobnie zreszta jak i pakiet biurowy oferowany przez Microsoft MS Office 2010, jest pod względem językowym produktem, w którym wykorzystano doświadczenia zebrane podczas ukrainizacji poprzednich platform. Opinia ta dotyczy również stron internetowych ${ }^{16}$ wspierających oba produkty. Oferują one użytkownikom pomoc w języku ukraińskim, co jeszcze nie tak dawno wcale nie było standardem, a ukraińskie komunikaty przechodziły w rosyjskie z reguły już na drugim czy trzecim poziomie menu nawigacji witryny.

Jak podkreśla wielu użytkowników ukraińskiej „Siódemki” jest to system zrusyfikowany w najmniejszym stopniu, a przekład warstwy tekstowej systemu stoi na zadawalającym poziomie.

Wydaje się, że o taki efekt byłoby trudno, gdyby nie ukraińscy uczeni i thumacze współpracujący z koncernem z Redmond, ale również tłumacze, którzy ukrainizowali ten i poprzednie systemy operacyjne na własną rękę, a pliki ukrainizacyjne udostępniali w Sieci. Śledząc przeróżne fora internetowe, na których toczyły się zaciekłe dyskusje na temat zagadnień przekładu poszczególnych segmentów oprogramowania Microsoftu, można odnieść wrażenie, że gdyby nie ten pośredni „nacisk”, efekt działań thumaczy mógłby być nieco inny.

Należy podkreślić, że tłumacze niejako amatorsko ${ }^{17}$ pracujący nad lokalizacją produktów Microsoftu, zajmowali się, i zajmują się nadal, ukrainizowaniem warstw słownych innych typów oprogramowania. Forum, na którym kwestie dostosowywania oprogramowania światowych producentów dla potrzeb ukraińskiego odbiorcy są jednym $\mathrm{z}$ wiodących wątków, jest to „podczepione” do wspomnianego wyżej portalu Домівка.Net. „Українізація ПЗ” jest jednym z najczęściej odwiedzanych wątków w dziale „Високі технологіï”. Pod koniec maja br składał się on z ponad stu tematów, a liczba zamieszczonych tam postów sięgnęła prawie 4 tys., co stawia go w czołówce wszystkich wątków zamieszczanych na tym portalu. O poziomie thumaczy będących stałymi uczestnikami tego forum, świadczą oferty firm tłumaczeniowych na nim zamieszczane, dotyczące konkretnych zleceń, np. „Ласкаво просимо! Студія Мод.UA запрошує розробників українських ігрових модифікацій до співпраці; !!!ДО СПІВПРАЦІ!!! Усім, хто має бажання до перекладу на українську (з рос. чи англ.) програм я готовий надати всю наявну інформацію, поділитись досвідом... $€$ можливість, якщо Ви мешкаєте у Києві, запису на компакт-диск необхідного ПЗ і довідкової інформації з процесу перекладу", albo: „У тебе є вільний час? Ти хочеш зробити добре діло? Бажаєш, щоб у відомій грі дядьки верещали “Надаємо їм копняків"? :) Хочеш побачити своє ім'я у списку розробників гри? Тоді долучайся до команди перекладу ігор українською на http://uagamer.net" i in.

Wśród omawianych przekładów oprogramowania, prócz produktów Microsoftu, znalazły się thumaczenia takich programów i gier jak: Camtasia Studio 7.1, Comodo Internet Security, CMS, Defraggler, foobar2000, GomPlayer, Google Talk, ICQ, Winamp, ArchiVid, VyChat 2.1, QIP, Skype, Nero Burning Rom, PHP-Nuke, CounterStrike, Blitzkrieg i wielu innych.

${ }^{15}$ Zob. np.: Електронний ресурс: http://defis.lviv.ua/227-antyvirusy.html, http://www.terra.rv.ua/ portal/?guest, http://www.ktc-ua.com/catalog/os, http://www.diawest.com/catalog/category/63/ (05.06.2012).

16 Źródła elektroniczne: http://office.microsoft.com/uk-ua/products/?CTT=97, http://windows. microsoft.com/uk-UA/windows/home (05.06.2012).

${ }^{17}$ Stwierdzenie to nie jest może do końca adekwatne: „amatorsko” tzn. nie na zlecenie producenta danego programu. 
Niejednokrotnie użytkownicy forum pomagają sobie wzajemnie w odnalezieniu najlepszych wariantów dla poszczególnych partii tekstu umieszczając je w kolejnych postach, np. ${ }^{18}$ :

1.

Invert message sending mode with new line — Повідомлення зворотнього зв'язку посилається 3 нового рядка

Avatar - Уособлення

Ignore mass private messages - Нехтувати масовими приватними повідомленнями

Show received message delimiter - Показувати розділювач повідомлень

Time to live — Час для життя

OutBox — Вихідна скринька

The username is link for private reports (/msg “user”) — Ім'я користувача $\epsilon$ зв'язком для приватних повідомлень

Limit smiles — Межа усмішок

2.

Invert message sending mode with new line - Обернений режим надсилання повідомлень 3 нового рядка

Avatar - Аватар

Ignore mass private messages - Ігнорувати масові приватні повідомлення

Show received message delimiter - Показувати розділювач повідомлень

Time to live — Час чинності

OutBox - Вихідні

The username is link fot PM (/msg “user”) — Ім'я користувача $є$ посиланням на ПП (/msg “користувач”)

Limit smiles — Обмеження (ліміт) усмішок

3.

Invert message sending mode with new line - Обернений режим надсилання повідомлень 3 нового рядка

Avatar - Аватар

Ignore mass private messages - Ігнорувати масові ПП

Show received message delimiter - Показувати розділювач повідомлень

Time to live — Час чинності

OutBox - Вихідні

The username is link fot PM (/msg “user”) — Псевдо [користувача] є посиланням на ПП

Limit smiles - Обмеження (ліміт) усмішок (емоцій)

Z efektami pracy tłumaczy można zapoznać się również na wielu innych stronach $\mathrm{z}$ ukrainizatorami oprogramowania, m. in. http://playua.net/category/ ukrayinizatori/, http://ukrstreet.net/load/ukrajinizatori/7, http://localize.org. ua/?q=glossary, http://toloka.hurtom.com/viewforum.php?f=29, http://linux.org.ua/ cgi-bin/yabb/YaBB.pl?board=translate $\mathrm{i}$ in.

Na wymienionych witrynach umieszczono ukraińskojęzyczne pliki lokalizujące do takich programów użytkowych i gier jak np. Max Payne, Alien Swarm, Steam,

\footnotetext{
${ }^{18}$ Електронний ресурс: http://domivka.net/archive/t-3860.html (15.09.2012).
} 
Nero Multimedia Suite, Grand Theft Auto IV, Corel VideoStudio, Medal of Honor: Airborne, FlatOut, Silent Hunter III, S.T.A.L.K.E.R, NFS Most Wanted, Maxthon, PowerChute Personal Edition, Radialix, STDU Viewer, TagScanner, Visual Basic, $\mu$ Torrent, World of Tanks, Crysis $2 \mathrm{i}$ in.

Nakładki językowe, np. w przypadku gier przygodowych w formie podpisów ukazujących się u dołu ekranu czy ukraińskiej wersji audio, instalowane są na angielskiej lub rosyjskiej wersji danego programu modyfikując tym samym formę „komunikowania się" użytkownika z komputerem.

Trudno stwierdzić, w jakim stopniu poziom plików ukrainizujących wymienione programy odbiega od ich tłumaczeń,,fabrycznych”, ponieważniezwykle rzadko można takiego porównania dokonać. Przeszkodą jest tu deficyt materiału porównawczego, czy to z racji jego rzeczywistego braku, czy niemożności jego zdobycia.

Może się wydawać, że funkcjonowanie ukraińskojęzycznych produktów informatycznych, w warunkach, gdy 56\% obywateli Ukrainy uważa język ukraiński za ojczysty ${ }^{19}$, nie powinno być problemem. Tak duży rynek zbytu sprzętu i oprogramowania powinien być pełen produktów opatrzonych znaczkiem UKR. Dlaczego tak jednak nie jest? Dlaczego, np. na odbywającym się w br we Lwowie jubileuszowym 20. Forum Wydawców, książek z dziedziny informatyki napisanych po ukraińsku w zasadzie nie było, natomiast stoisk z bogatą literaturą informatyczną w języku rosyjskim uruchomiono co najmniej kilka?

Odpowiedź na te i podobne pytania może być bardzo rozbudowana lub też może sprowadzać się do kilku zaledwie spostrzeżeń: 1) producentom oprogramowania nie opłaca się tłumaczyć swych produktów na język ukraiński, gdyż wychodzą oni z założenia, że ich rosyjskojęzyczny „software” sprzeda się tak w Rosji, jak i na Ukrainie oraz innych państwach byłego ZSRR; 2) rynek informatyczny na Ukrainie w większości pozostaje w rękach firm rosyjskich / „rosyjskojęzycznych”, a co za tym idzie nie jest on zorientowany na produkcję ukraińskojęzyczną; 3) produkty ukraińskojęzyczne są celowo pomijane przy dystrybucji; 4) ukraińskim konsumentom jest być może obojętne w jakim języku odbywa się ich dialog z komputerem.

Jak zatem w świetle powyższych faktów przedstawia się kwestia ukraińskiej lokalizacji oprogramowania? Przegląd półek sklepowych oraz zasobów sklepów internetowych oferujących różnego typu oprogramowanie komputerowe nie pozostawia złudzeń - na większości z nich dominują produkty rosyjskojęzyczne. Oprogramowanie tłumaczone na język ukraiński stanowi niewielki odsetek oferty sklepowej. W takich warunkach ukrainizacja przeniosła się niejako do podziemia, a za tłumaczenie produktów informatycznych na język ukraiński wzięły się osoby prywatne. Jest to niewatpliwie sytuacja daleko odbiegająca od normy. Wprawdzie dobrze ona świadczy o ukraińskich informatykach-tłumaczach, jednak jednocześnie ukazuje głęboką patologię nie tylko ukraińskiego sektora informatycznego, ale pośrednio gospodarczego czy politycznego.

19 Dane na marzec 2013 r. za: Електронний pecypc: http://www.kiis.com.ua/materials/pr/ 20130321_ForAff/foreign_affairs.pdf(16.09.2013). 